\title{
Evaluation of the effect of aromatase inhibitor in reducing the size of endometrioma
}

\author{
Selina Afroz Ansary 1,2*, Shakeela Ishrat ${ }^{2}$, Jesmine Banu², Parveen Fatima ${ }^{2}$, Faria Nasreen ${ }^{3}$, \\ Israt Jahan $^{1,2}$, Shajia Afrin ${ }^{1,2}$, Khaleda Nasreen ${ }^{1,2}$, Mohammad Mohsin ${ }^{4}$
}

\author{
${ }^{1}$ Junior Consultant, OSD (DGH, Mhakhali) Attachment, ${ }^{2}$ Department of Reproductive Endocrinology and Infertility, \\ BSMMU, Dhaka, Bangladesh \\ ${ }^{3}$ National Institute of Nuclear Medicine and Allied Sciences (NINMAS), Dhaka, Bangladesh \\ ${ }^{4}$ Department of Critical Care Medicine, OSD (DGHS, Mohakhali), Attachment-Dhaka Medical College, Bangladesh
}

Received: 06 January 2021

Accepted: 06 February 2021

\section{*Correspondence:}

Dr. Selina Afroz Ansary,

E-mail: drselinaafroz@gmail.com

Copyright: (C) the author(s), publisher and licensee Medip Academy. This is an open-access article distributed under the terms of the Creative Commons Attribution Non-Commercial License, which permits unrestricted non-commercial use, distribution, and reproduction in any medium, provided the original work is properly cited.

\begin{abstract}
Background: Endometriosis is a chronic and progressive estrogen-dependent disorder that can result in substantial morbidity, including pelvic pain, multiple operations, and infertility. Endometriosis can be ovarian, peritoneal or deep infiltrative. Blocking estrogen production by inhibiting aromatization, aromatase inhibitor (letrozole) has been shown to reduce the size of endometrioma and endometriosis associated pain. Aim of the study was to evaluate the effect of aromatase inhibitor in reducing the size of endometrioma.

Methods: A prospective non comparative observational study was conducted in the Department of Reproductive Endocrinology and Infertility of BSMMU on 30 women with ovarian endometrioma during the period of April 2019 to March 2020. Women were treated with aromatase inhibitor (letrozole) $2.5 \mathrm{mg}$, norethisterone $5 \mathrm{mg}$, calcium 1200 $\mathrm{mg}$, and vitamin D 800 IU daily for 6 months. Transvaginal ultrasound was performed at baseline, 3 months and 6 months after treatment to assess the mean diameter and volume of endometriomas. Statistical analyses were carried out by using the Statistical Package for Social Sciences version 23.0.

Results: More than $50 \%$ reduction in volume occurred in $90 \%$ of endometrioma. In one (3.3\%) case endometrioma disappeared completely after 6 months. There was statistically significant reduction of size of endometrioma (estimated by mean diameter and volume) and pain. Volume decrease was linearly related to baseline endometrioma volume and inversely related to baseline body mass index (BMI). The side effects were mild and well tolerated by the patients.

Conclusions: Treatment of ovarian endometrioma with aromatase inhibitor combined with progestin add-back for 6 months cause substantial reduction in size of endometrioma and associated pain.
\end{abstract}

Keywords: Aromatase inhibitor, Endometrioma

\section{INTRODUCTION}

Endometriosis is one of the most challenging gynecological disorders of our era that is defined by the presence of endometrial glands and stroma outside the uterus. ${ }^{1}$ It is an estrogen dependent chronic inflammatory disease affecting $5 \%-10 \%$ of women of reproductive age. ${ }^{2}$ In 2010 endometriosis was estimated to affect 176 million women of child-bearing potential all over the world. ${ }^{3}$ In the $30-40 \%$ of cases, women may be asymptomatic, but the majority presents with pelvic pain, infertility, or an adnexal mass. ${ }^{4}$ Ovarian endometrioma affects $17-44 \%$ of women suffering from endometriosis and is one of the most common manifestations of the disease. $^{5}$ Endometrioma itself could impair the ovarian function. It contains high levels of cellular damage mediating factors, proteolytic enzymes, inflammatory molecules, reactive oxygen species. ${ }^{6}$ There are immune, 
environmental and genetic factors behind the etiology of endometriosis. The enzyme aromatase catalyzes the conversion of C19 steroids to estrogens. Estrogens stimulate cyclooxygenase 2 to increase the levels of prostaglandin E2 (PGE2) which in turn, induce aromatase activity in endometriotic stromal cells. ${ }^{7}$ As association or sequential to above mentioned factors, endometrial lesions have high estradiol biosynthesis and low estradiol (E2) inactivation in comparison to normal eutopic endometrium. Abundant steroidogenic acute regulatory protein (STAR) activity and aromatase enzyme activity in stromal cells isolated and cultured from endometriomas. ${ }^{8,9}$ The above findings provide the basis for clinical trials with aromatase inhibitors in women with endometriosis. The aromatase enzyme is the final enzyme in the estrogen biosynthesis pathway and its inhibition effectively stops estrogen production. The review on published clinical evidences of the role of aromatase inhibitors in the treatment of endometriosis by Attar and Bulun, concluded that aromatase inhibitor reduced lesion size significantly and treated pelvic pain successfully. ${ }^{10}$ Medical therapies other than aromatase inhibitors only inhibit estrogen action or its production from the ovaries, do not inhibit local estrogen production in endometriotic implants. ${ }^{7,11}$ An aromatase inhibitor has unique ability to work at both the level of the ovary and locally in the endometriotic tissue. Blocking estrogen production by inhibiting aromatization, aromatase inhibitor will cause regression of endometrioma. With this background aromatase inhibitor, letrozole may be a promising new therapeutic option in the treatment of young women with endometrioma who are keen on avoiding surgery.

\section{Objectives}

General objective: To evaluate the effect of aromatase inhibitor in reducing the size of endometrioma.

Specific objectives: To observe the pre-treatment mean diameter and volume of endometrioma. To measure the mean diameter and volume of endometrioma at the end of 3 months post-treatment. To observe the mean diameter and volume of endometrioma at the end of 6 months posttreatment. To assess the change in pain level. To assess side effects during and after treatment. To analyse the factors predicting reduction in the size of endometrioma.

\section{METHODS}

This was a prospective non comparative observational study and was conducted in the Department of Reproductive Endocrinology and Infertility, Bangabandhu Sheikh Mujib Medical University, Dhaka, Bangladesh during the period of April 2019 to March 2020. The sample size was 30 . Statistical analyses were carried out by using the Statistical Package for Social Sciences version 23.0 for Windows (SPSS Inc., Chicago, Illinois, USA).

\section{Inclusion criteria}

Age 18 to 35 years. Not wishing to conceive over the ensuing 6 months due to financial problems, carrier plan and staying of husband in abroad. Endometrioma and recurrent endometrioma after surgical excision demonstrated by strict sonographic criteria (mean diameters 3-7 cm).

\section{Exclusion criteria}

Undiagnosed vaginal bleeding. Any sensitivity to letrozole or norethisterone. Current or past history of seizure disorders. Known case of diabetes, pulmonary, cardiac, renal or hepatic disease. Previous use of aromatase inhibitors. Use of hormonal therapies in the three months prior to inclusion in the study. Unwillingness to tolerate menstrual changes. Desire for immediate surgery and fertility treatment. Known case of any psychiatric disturbances. History of drug and alcohol abuse.

\section{RESULTS}

A total of 30 women completed the treatment course of 6 months and was included in analysis. The sociodemographic characteristics of the 30 women who completed the study are reported in Table 1 .

Table 1: Socio demographic characteristics of the study populations $(n=30)$.

\begin{tabular}{|c|c|c|c|}
\hline Characteristics & & $\mathbf{n}$ & $\%$ \\
\hline \multirow{4}{*}{ Age (years) } & $\leq 30$ & 27 & 90 \\
\hline & $>30$ & 3 & 10 \\
\hline & Mean \pm SD & \multicolumn{2}{|c|}{$27.7 \pm 3.06$} \\
\hline & Range (min-max) & \multicolumn{2}{|c|}{$22-34$} \\
\hline \multirow{4}{*}{$\begin{array}{l}\text { Duration of } \\
\text { marriage } \\
\text { (years) }\end{array}$} & $\leq 10$ & 23 & 76.7 \\
\hline & $>10$ & 7 & 23.3 \\
\hline & Mean \pm SD & \multicolumn{2}{|c|}{$6.81 \pm 4.3$} \\
\hline & Range (min-max) & \multicolumn{2}{|c|}{$0.6-17$} \\
\hline \multirow{2}{*}{ Para } & Nulliparous & 23 & 76.7 \\
\hline & Parous & 7 & 23.3 \\
\hline \multirow{3}{*}{$\begin{array}{l}\text { Monthly } \\
\text { income (Taka) }\end{array}$} & $10,000-20,000$ & 6 & 20 \\
\hline & $>20,000-50,000$ & 20 & 66.7 \\
\hline & $>50,000$ & 4 & 13.3 \\
\hline \multirow{3}{*}{$\begin{array}{l}\text { Educational } \\
\text { status }\end{array}$} & Primary & 7 & 23.3 \\
\hline & Secondary & 14 & 46.7 \\
\hline & Higher Secondary & 9 & 30 \\
\hline \multirow{3}{*}{ Occupation } & House wife & 26 & 86.7 \\
\hline & Govt. Service & 1 & 3.3 \\
\hline & Private service & 3 & 10 \\
\hline \multirow{3}{*}{$\begin{array}{l}\text { Husbands } \\
\text { occupation }\end{array}$} & Service & 11 & 36.7 \\
\hline & Business & 11 & 36.7 \\
\hline & Staying abroad & 8 & 26.6 \\
\hline \multirow{2}{*}{ Habitant } & Urban & 23 & 76.7 \\
\hline & Rural & 7 & 23.3 \\
\hline
\end{tabular}


Table 2: Clinical characteristics of the study populations $(n=30)$.

\begin{tabular}{|llll|}
\hline Characteristics & n & $\%$ \\
\hline Unilateral endometrioma & 26 & 86.7 \\
\hline Bilateral endometrioma & 4 & 13.3 \\
\hline & Only dysmenorrhea & 19 & 63.3 \\
\cline { 2 - 4 } & $\begin{array}{l}\text { Dysmenorrhea and deep } \\
\text { dyspareunia }\end{array}$ & 3 & 10 \\
\cline { 2 - 4 } $\begin{array}{l}\text { Type of } \\
\text { pelvic pain }\end{array}$ & $\begin{array}{l}\text { Dysmenorrhea and inter- } \\
\text { menstrual pain }\end{array}$ & 3 & 10 \\
\cline { 2 - 4 } & None & 5 & 16.7 \\
\hline $\begin{array}{l}\text { Previous } \\
\text { medical } \\
\text { treatment }\end{array}$ & Oral contraceptive pill & 12 & 40 \\
\cline { 2 - 4 } & Norethisterone acetate & 10 & 33.3 \\
\cline { 2 - 4 } & NSAIDs & 5 & 16.7 \\
\hline $\begin{array}{l}\text { Previous } \\
\text { hormonal } \\
\text { medication } \\
\text { or non- } \\
\text { hormonal } \\
\text { medication }\end{array}$ & No & 5 & 10 \\
\cline { 2 - 4 } & Yes & 25.7 \\
\hline \multirow{2}{*}{$\begin{array}{l}\text { Previous } \\
\text { surgical } \\
\text { treatment }\end{array}$} & $\begin{array}{l}\text { Laparotomy with ovarian } \\
\text { cystectomy }\end{array}$ & 3 & 10 \\
\cline { 2 - 4 } & $\begin{array}{l}\text { Laparoscopy with ovarian } \\
\text { cystectomy }\end{array}$ & 2 & 6.7 \\
\hline
\end{tabular}

The mean age was $27.7 \pm 3.06$ years with age range 22 to 34 years. Most of the studied patients (76.7\%) were nulliparous while only $23.3 \%$ were parous. Among the thirty women $4(13.3 \%)$ had bilateral endometriomas. Among bilateral endometrioma larger mean diameter and volume of endometrioma were included in statistical analysis. Of the studied patients, $16.7 \%$ women were asymptomatic. There was history of previous surgery in 5 (16.7\%) women (Table 2).

Table 3: Measurements of endometrioma at baseline, 3 months and 6 months $(n=30)$.

\begin{tabular}{|c|c|c|}
\hline \multicolumn{2}{|c|}{ Measurements } & Mean \pm SD \\
\hline \multirow{5}{*}{$\begin{array}{l}\text { Size } \\
\text { (mean } \\
\text { diameter) }\end{array}$} & Baseline $(\mathrm{cm})$ & $5.05 \pm 0.87$ \\
\hline & 3 months after treatment $(\mathrm{cm})$ & $4.05 \pm 0.88$ \\
\hline & $\begin{array}{l}\text { Percentage reduction at } 3 \\
\text { months }(\%)\end{array}$ & $19.72 \pm 9.96$ \\
\hline & 6 months after treatment $(\mathrm{cm})$ & $3.11 \pm 1.01$ \\
\hline & $\begin{array}{l}\text { Percentage reduction at } 6 \\
\text { months }(\%)\end{array}$ & $40.59 \pm 20.06$ \\
\hline \multirow{5}{*}{ Volume } & Baseline $\left(\mathrm{cm}^{3}\right)$ & $63.4 \pm 27.98$ \\
\hline & 3 months after treatment $\left(\mathrm{cm}^{3}\right)$ & $29.37 \pm 14.12$ \\
\hline & $\begin{array}{l}\text { Percentage reduction at } 3 \\
\text { months }(\%)\end{array}$ & $53.94 \pm 11.45$ \\
\hline & 6 months after treatment $\left(\mathrm{cm}^{3}\right)$ & $12.7 \pm 15.58$ \\
\hline & $\begin{array}{l}\text { Percentage reduction at } 6 \\
\text { months }(\%)\end{array}$ & $81.96 \pm 15.17$ \\
\hline
\end{tabular}

A summary of endometrioma scores is shown in Table 3. At baseline, the mean diameter of the endometrioma was $5.05 \pm 0.87 \mathrm{~cm}$ with range $3.1-6.75 \mathrm{~cm}$. More than $50 \%$ reduction in volume occurred in $90 \%$ of endometrioma. No new endometrioma developed during the follow-up period. In only 2 cases $(6.7 \%)$ mean endometrioma diameter did not decrease. In one case endometrioma disappeared completely after 6 months. There was statistically significant $(\mathrm{p} \leq 0.001)$ decrease in the size of endometrioma from baseline to observations at follow up after 3 months and 6 months. The magnitude of effects was large.

Table 4: Changes in endometrioma $(n=30)$.

\begin{tabular}{|c|c|c|c|c|c|c|c|}
\hline \multirow[t]{2}{*}{ Characteristics } & & \multirow[t]{2}{*}{ Mean \pm SD } & \multicolumn{2}{|c|}{$\begin{array}{l}95 \% \text { CI of } \\
\text { difference }\end{array}$} & \multirow[t]{2}{*}{$P$ value } & \multirow[t]{2}{*}{ 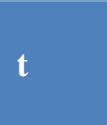 } & \multirow{2}{*}{$\begin{array}{l}\text { Cohen's } \\
\text { D }\end{array}$} \\
\hline & & & Lower & Upper & & & \\
\hline \multirow{2}{*}{$\begin{array}{l}\text { Net change in size (mean } \\
\text { diameter) of } \\
\text { endometrioma }(\mathrm{cm})\end{array}$} & Baseline versus after 3 months & $0.99 \pm 0.55$ & 0.79 & 1.2 & $0.000^{\mathrm{s}}$ & 9.89 & 1.81 \\
\hline & Baseline versus after 6 months & $1.98 \pm 1.02$ & 1.59 & 2.37 & $0.000^{\mathrm{s}}$ & 10.4 & 1.93 \\
\hline $\begin{array}{l}\text { Difference in percentage } \\
\text { reduction of diameter }\end{array}$ & $\begin{array}{l}\text { After } 3 \text { months versus after } 6 \\
\text { months }\end{array}$ & $20.87 \pm 13.79$ & 15.72 & 26.02 & $0.000^{\mathrm{s}}$ & 8.29 & 1.53 \\
\hline \multirow{2}{*}{$\begin{array}{l}\text { Net change in mean } \\
\text { volume of endometrioma } \\
\text { (cc) }\end{array}$} & Baseline versus 3 months & $34.04 \pm 17.42$ & 33.07 & 35.01 & $0.000^{\mathrm{s}}$ & 68.81 & 12.55 \\
\hline & Baseline versus 6 months & $50.71 \pm 25.04$ & 49.31 & 52.10 & $0.000^{\mathrm{s}}$ & 71.31 & 13.01 \\
\hline $\begin{array}{l}\text { Difference in percentage } \\
\text { reduction of volume }\end{array}$ & $\begin{array}{l}\text { After } 3 \text { months versus after } 6 \\
\text { months }\end{array}$ & $0.276 \pm 0.166$ & 0.267 & 0.285 & $0.000^{\mathrm{s}}$ & 57.70 & 10.53 \\
\hline \multirow{2}{*}{$\begin{array}{l}\text { Net change in mean VAS } \\
\text { score }(\mathrm{cm})\end{array}$} & Baseline versus after 3 months & $2.7 \pm 0.75$ & 2 & 3.4 & $0.039^{\mathrm{s}}$ & 4.9 & 3.6 \\
\hline & Baseline versus after 6 months & & 0.53 & 8.1 & $0.000^{\mathrm{s}}$ & 9.5 & \\
\hline \multirow{2}{*}{$\begin{array}{l}\text { Net change in BMI } \\
\left(\mathrm{kg} / \mathrm{m}^{2}\right)\end{array}$} & $\begin{array}{l}\text { Baseline versus } 3 \text { months after } \\
\text { treatment }\end{array}$ & $34.04 \pm 17.42$ & 33.07 & 35.01 & $0.012^{\mathrm{s}}$ & 2.67 & 0.48 \\
\hline & $\begin{array}{l}\text { Baseline versus } 6 \text { months after } \\
\text { treatment }\end{array}$ & $25.10 \pm 2.8$ & 49.31 & 52.1 & $0.000^{\mathrm{s}}$ & 6.17 & 1.12 \\
\hline
\end{tabular}


From Table 4, we found that the percentage reduction in mean diameter of endometrioma from baseline was significantly more after 6 months compared to that after 3 months follow up $(\mathrm{p}<0.001)$. Effect size was large. There was statistically significant decrease $(p \leq 0.001)$ in mean volume of endometrioma from baseline to observations after 3 months and 6 months follow up. The percentage reduction in volume of endometrioma from baseline was significantly more $(\mathrm{p}<0.001)$ after 6 months compared to that after 3 months follow up. The magnitude of decrease was large. Of the 30 women, five women were asymptomatic with no pain. Of the remaining 25 women, deep dyspareunia and inter-menstrual pain with VAS score $\leq 3$ was present in 6 women in addition to dysmenorrhea. Since these pain symptoms were relatively infrequent and the VAS score was negligible these were excluded from analysis. Baseline VAS score range of studied patients for dysmenorrhea was 4-10, for deep dyspareunia 1-3 and for inter-menstrual pain 1-2. Statistical analysis of 25 patients with VAS score for dysmenorrhea ( $\geq 4$ at base line) was done here. Comparison of pain scores before and after treatment demonstrated a significant reduction in pain from initial levels. There was significant decrease in pain score (visual analogue scale) from baseline to observations after 3 and 6 months follow up. Magnitude of decrease was large after 3 and 6 months. Mean BMI of the studied patients was found $23.5 \pm 3 \mathrm{~kg} / \mathrm{m}^{2}$ at baseline. There was significant rise in BMI from baseline to observations after $3(\mathrm{p}<0.05)$ and 6 months $(\mathrm{p}<0.001)$ follow up. The magnitude of increase was moderate after 3 months, large after 6 months. The side effects during treatment are reported in Table 5.

Table 5: Side effects of the study patients $(n=30)$.

\begin{tabular}{|lllll|}
\hline \multirow{2}{*}{ Side effects } & \multicolumn{2}{l|}{$\mathbf{2}^{\text {nd }}$ visit $(\mathbf{n}=\mathbf{3 0})$} & $3^{\text {rd }}$ visit $(\mathbf{n}=\mathbf{3 0})$ \\
\hline Weight gain & $\mathbf{n}$ & $\mathbf{\%}$ & $\mathbf{n}$ & $\mathbf{\%}$ \\
\hline Arthralgia & 24 & 80.0 & 21 & 70.0 \\
\hline Myalgia & 8 & 26.7 & 7 & 23.3 \\
\hline Hair loss & 6 & 20.0 & 6 & 20.0 \\
\hline $\begin{array}{l}\text { Breakthrough } \\
\text { bleeding }\end{array}$ & 3 & 10.0 & 3 & 10.0 \\
\hline Decreased libido & 1 & 6.7 & 1 & 3.3 \\
\hline Hot flush & 1 & 3.3 & 1 & 3.3 \\
\hline
\end{tabular}

The most commonly experienced side effects included weight gain, arthralgia, myalgia, hair loss, breakthrough bleeding, decreased libido and hot flashes. The majority of these side effects were mild and well tolerated by the patients. The multiple linear regression model (Table 6) explained $79 \%$ variance in net change in volume of endometrioma over 6 months by the predictors. The table can be interpreted this way: for every one unit of change in baseline volume of endometrioma, the net change in volume over 6 months was 0.849 unit. The net change decreased by 2.505 units as baseline BMI increased by one unit. There was linear correlation between baseline volume and net reduction in volume over 6 months (Figure 1).

Table 6: Multiple linear regression analysis of predictors of net change in volume of endometrioma after 6 months $(\mathbf{n}=30)$.

\begin{tabular}{|lllll|}
\hline Predictors & $\begin{array}{l}\text { Unstandardized } \\
\text { coefficient }\end{array}$ & 95\% confidence interval of unstandardized coefficient & P value \\
\hline Age & 1.230 & 1.009 & Upper & $* 2.452$ \\
\hline Baseline BMI & -2.505 & -2.734 & -2.275 & $* 0.000$ \\
\hline $\begin{array}{l}\text { Baseline volume of } \\
\text { endometrioma }\end{array}$ & 0.849 & 0.824 & 0.873 & $* 0.000$ \\
\hline
\end{tabular}

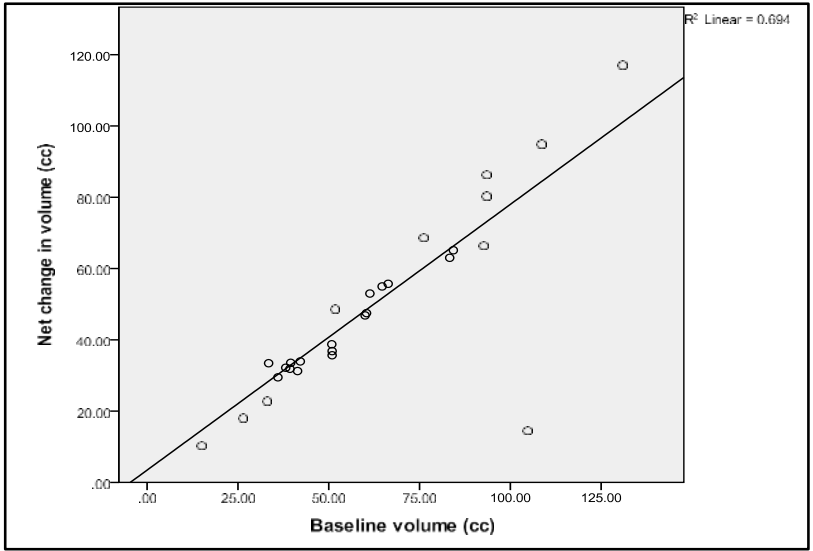

Figure-I: Correlation between baseline volume and net reduction in volume over 6 months.

\section{DISCUSSION}

The primary endpoint of this study was the change (reduction) in ultrasound documented endometrioma size. After 6 months follow up mean endometrioma diameter and volume decreased significantly. Endometriosis associated pain also improved with the treatment. Agarwal et al, USA showed mean endometrioma volume reduction of $75 \%$ at the end of three months which was higher than the finding of the present study of $53.94 \%$, which may be explained by the double dose of letrozole (5 mg daily) used by them. ${ }^{12}$ Ferrero et al included women of relatively late reproductive age group and endometrioma size reduction was comparatively lower; they used same dose and duration of letrozole but half dose of norethisterone. ${ }^{13}$ The reduced response may be explained by higher age or lower dose of norethisterone. 
Seal et al stated the disappearance of ovarian endometriotic cysts in a case series at six months of treatment. ${ }^{14}$ They included only 5 women of advanced reproductive age group in a non-randomized proof of concept study. The mean reduction percentage of endometrioma volume with letrozole was more than that achieved with dienogest, OCP.15,16 Cyst volume reduction greater than $50 \%$ was achieved in $90 \%$ of women of the present study having letrozole, norethisterone for 6 months. Whereas, cyst volume reduction greater than $50 \%$ was achieved by Xholli et al in $90 \%$ of women receiving dienogest $2 \mathrm{mg}$ /day for 12 months.17 Question may arise whether significant reduction in endometrioma sizes is due to letrozole itself or due to norethisterone acetate or synergistic effect of the two. Norethisterone acts via gonadotropin suppression. Matrix metalloproteinase activity in eutopic endometrium of women with endometriosis is unusually resistant to progesterone suppression. ${ }^{18}$ Higher doses are usually needed for the treatment of endometriosis to overcome progesterone resistance. The recommended dose of norethisterone acetate for patients with endometriosis is $15 \mathrm{mg} /$ day which is much higher than that prescribed in this study. ${ }^{19}$ It can be concluded that letrozole has the major contribution. The percentage reduction volume of endometrioma by letrozole, $2.5 \mathrm{mg}$ combined with norethisterone $5 \mathrm{mg}$ for 6 months was $81.96 \%$ compared to $37.2 \%$ achieved norethisterone, $5 \mathrm{mg}$ for 6 months. ${ }^{20} \mathrm{It}$ appears that letrozole combined with norethisterone is more efficacious than norethisterone alone in reducing the volume of endometriotic cysts. It was observed that present study as well as studies by Ailawadi et al; Remorgida et al; Ferrero et al used similar type of regimens. ${ }^{13,21,22}$ In these studies, norethisterone was used along with aromatase inhibitor as this progestin is unique in having estrogenic metabolites and a well-documented effect on bone density that is distinct from other progestins. $^{23}$ Norethisterone acetate $5 \mathrm{mg}$ is the recommended add-back dose to minimize hot flushes and bone loss in patients with endometriosis receiving $\mathrm{GnRH}$ agonist (Practice Committee of the American Society for Reproductive Medicine). ${ }^{24}$ Calcium and vitamin D supplements were also included in the regimen to reduce possible treatment associated bone loss. ${ }^{25}$ On the other hand, Takayama et al; Razzi et al; Fatemi et al and Hefler et al; did not advise progestin. Amsterdam et al and Remorgida et al used oral contraceptive pill as an effective method of contraception. ${ }^{26-31}$ Similar to a study by Remorgida et al subjects of present study were advised to use barrier method of contraception. ${ }^{22}$ The baseline VAS score was lower in women of the present study than others. This may be due to the selection of women who primarily presents with endometrioma or because they have lower sensitivity to pain than other ethnic population. All studies had significant reduction in pain with aromatase inhibitors. Madny, and Verma et al had significant reduction in pain score, but the final VAS score is higher than that in present study. ${ }^{32,33}$ Both studies used aromatase inhibitors without norethisterone. So, norethisterone may have an additional effect on pain reduction. Comparative studies such as norethisterone versus letrozole plus norethisterone observed no significant difference in the amelioration of pain symptoms. ${ }^{13}$ Letrozole may not have an additional effect on the pain reduction provided by norethisterone alone. However, it is apparent from other studies by Takayama et al; Razzi et al; Fatemi et al; Hefler et al; Verma et al; Madny that letrozole alone can cause significant improvement in pain score..$^{26-29,32,33}$ The differential response to pain can be explained by difference in pain sensitivity or lack of correlation between pain and severity of endometriosis. In this study there was significant rise in BMI from baseline to observations after 3 and 6 months follow up. Baseline BMI of present study population was comparable to other studies with letrozole, but other studies did not measure BMI at follow up visits. Present study found weight gain in $80 \%$ cases after $2^{\text {nd }}$ visit and in $70 \%$ cases after $3^{\text {rd }}$ visit. So, it appears increased weight gain became less with time, which may be an effect of counselling for diet and exercise. Weight gain was higher in women of present study receiving letrozole. Muneyyirci-Delale et al reported weight gain in $83.33 \%$ women receiving norethisterone $5 \mathrm{mg} .{ }^{34}$ Del Forno et al observed weight gain in $15.9 \%$ cases receiving dienogest and in $34.8 \%$ women receiving norethindrone acetate. ${ }^{35}$ The variation in weight gain may be due to confounding factors like lifestyle, diet and ethnicity. It is understandable that more weight gain was observed in studies containing progestins such as norethisterone/ norethindrone acetate or desogestrel or dienogest. ${ }^{22,31,34-36}$ So, the additional weight gain was probably due to progestin, not letrozole. Findings of myalgia and hair loss were similar between present study and study by Ferrero et al and that of arthralgia was somewhat more than that of others. ${ }^{13}$ This study found decreased libido in $3.3 \%$ subjects, which was lower than other studies with women receiving letrozole, dienogest or norehisterone acetate. Del Forno et al found decreased libido in $8.7 \%$ patients receiving dienogest and in $16.7 \%$ cases receiving norethindrone acetate. ${ }^{35}$ Breakthrough bleeding was present in $6.7 \%(n=2)$ women of the present study after 3 months and in $3.3 \%(n=1)$ women after 6 months follow up visit, lower than other studies with women receiving letrozole. The side effect of breakthrough bleeding appeared to become less with time. Breakthrough bleeding was reported in $44.44 \%$ women receiving norethindrone acetate but was tolerated, caused no discontinuations and remedied by increasing the dose by $2.5 \mathrm{mg}$ until resolved. ${ }^{34}$ Breakthrough bleeding in this study was stabilized with short course of estradiol valerate. Additional side effects such as depression, fatigue, headache, nausea peripheral edema, vaginal dryness, mood changes, irritability and breast tenderness were observed in studies on women having OCP with letrozole. ${ }^{31,36}$ There was development of ovarian cyst in two studies. One was a retrospective analysis of 16 patients (median age 28 years), for pain as primary outcome. ${ }^{36}$ The study included 3 women with coexisting ovarian cyst and reported 2 women developing ovarian cyst. The ovarian cysts were not categorized as simple or 
chocolate cyst. Another prospective observational study of 12 women with laparoscopicaly diagnosed endometriosis having letrozole $2.5 \mathrm{mg}$ daily with desogestrel $75 \mu \mathrm{gm}$ for 6 months reported that all women abandoned study due to development of functional ovarian cysts. ${ }^{31}$ The study did transvaginal sonogram at monthly interval and noted functional cyst at 2, 3 and 4 months. The study excluded women with chocolate cyst and functional cysts, but all women of present study had chocolate cysts, already in advanced stage of endometriosis. Letrozole may stimulate available antral follicles and induce pregnancy which was apparent from a later study on women with adenomyosis receiving daily $2.5 \mathrm{mg}$ letrozole for 6 months. ${ }^{37}$ Why developing follicles did not ovulate can be explained by endometriosis. Present study as well as other studies by Seal et al; study by Ferrero et al did not reveal any evidence of ovarian cyst formation. ${ }^{13,14}$ The potential explanations for this are: 1) chronic exposure to letrozole at $2.5 \mathrm{mg} /$ day for 6 months does not cause formation of ovarian cysts, 2) potential stimulatory effects of letrozole on gonadotropins were counteracted by norethisterone acetate. ${ }^{22}$ 3) The response may be blunted by the presence of endometrioma. The short-term administration of aromatase inhibitor was not associated with significant reduction of spine and hip-bone densities in either premenopausal or postmenopausal patients. ${ }^{21,23,26-31}$ Aromatase inhibitors along with progestins or OCPs do not appear to be associated with significant bone loss even after 6 months of treatment and therefore may be suitable for long-term use. ${ }^{10}$ Increased risks of osteoporosis and fracture rates of $2-11 \%$ have been reported in some studies with years of use of aromatase inhibitors. ${ }^{38-41}$ So, the American Society of Clinical Oncologists recommends annual BMD screening and administration of bisphosphonate therapy when measurement of the BMD in terms of T-score are -2.5 or lower for breast cancer patients using aromatase inhibitor adjuvant therapy. ${ }^{42}$ Linear regression analysis was used to evaluate whether the extent of volume change (net change; dependent variable) was related to the baseline volume of endometrioma, age, body mass index (independent variables). The linear relation was observed between baseline volume and net change in volume. This finding was consistent with the finding in a study by Xholli et al. ${ }^{17}$ In this study there were three pregnancies $(10 \%)$ in the follow up period after completion of 6 months treatment. Similarly, pregnancy after successful completion of treatment with aromatase inhibitor were also observed by Shippen et al; Verma et al; Seal et al and Abushahin et al. ${ }^{14,33,37,43}$

There are some limitations of the study. In our study, there was small sample size and absence of control for comparison. Study population was selected from one center in Dhaka city, so may not represent wider population. The study was conducted at a short period of time. The sampling was purposive and there was no random allocation, so there was risk of selection bias.

\section{CONCLUSION}

In our study, considering the chronic inflammatory and recurrent nature of endometriosis, we found that medical management may be a better option than surgery in selected population. As medical treatment, letrozole with norethisterone, calcium and vitamin D for not more than 6 months can be effective in rapid reduction of size of endometrioma and endometriosis associated pain with tolerable side effects. To further validate aromatase inhibitors as a treatment for endometriosis, randomized controlled double-blind clinical trial needs to be conducted. The trials may compare letrozole alone with estrogen progesterone pills or dienogest. Long-term follow-up studies are needed to see recurrences. Adverse effects with long-term use of letrozole in premenopausal women can be investigated. Future studies are necessary to determine pregnancy rates (PR) during or after aromatase inhibitor treatment for endometriosis.

Funding: No funding sources

Conflict of interest: None declared

Ethical approval: The study was approved by the Institutional Ethics Committee

\section{REFERENCES}

1. Vercellini P, Viganò $\mathrm{P}$, Somigliana E, Fedele L. Endometriosis: pathogenesis and treatment. Nat Rev Endocrinol. 2014;10(5):261-75.

2. Bulun SE. Endometriosis. N Engl J Med. 2009;360(3):268-79.

3. Adamson GD, Pasta DJ. 2010. Endometriosis fertility index: the new, validated endometriosis staging system. Fertil Steril. 2010;94(5):1609-15.

4. Giudice LC, Kao L. Endometriosis. Lancet. 2004;364(1):1789-99.

5. Busacca M, Vignali M. Ovarian endometriosis: from pathogenesis to surgical treatment. Curr Opin Obstet Gynecol. 2003;15(4):321-6.

6. Sanchez AM, Viganò $\mathrm{P}$, Somigliana E, PaninaBordignon P, Vercellini P, Candiani M. The distinguishing cellular and molecular features of the endometriotic ovarian cyst: from pathophysiology to the potential endometrioma-mediated damage to the ovary. Hum Reprod Update. 2014;20(2):217-30.

7. Bulun SE, Zeitoun K, Takayama K, Noble L, Michael D, Simpson E, et al. Estrogen production in endometriosis and use of aromatase inhibitors to treat endometriosis. Endocr Rel Cancer. 1999;6(2):293301.

8. Noble LS, Takayama K, Zeitoun KM, Putman JM, Johns DA, Hinshelwood MM, et al. 1997. Prostaglandin E2 stimulates aromatase expression in endometriosis-derived stromal cells. J Clin Endocrinol Metab. 1997;82(2):600-6.

9. Sun HS, Hsiao KY, Hsu CC, Wu MH, Tsai SJ, 2003. Transactivation of steroidogenic acute regulatory protein in human endometriotic stromal cells is 
mediated by the prostaglandin EP2 receptor. Endocrinology. 2003;144(9):3934-42.

10. Attar E, Bulun SE, 2006b. Aromatase inhibitors: the next generation of therapeutics for endometriosis? Fertil Steril. 2006;85(5):1307-18.

11. Zeitoun K, Takayama K, Sasano H, Suzuki T, Moghrabi N, Andersson S, et al. 1998. Deficient 17ß-hydroxysteroid dehydrogenase type 2 expression in endometriosis: failure to metabolize $17 \beta$-estradiol. J Clin Endocrinol Metab. 1998;83(12):4474-80.

12. Agarwal SK, Foster WG. Reduction in endometrioma size with three months of aromatase inhibition and progestin add-back. Bio Med Res Int. 2015;2015.

13. Ferrero S, Remorgida V, Venturini PL, Maggiore ULR. Norethisterone acetate versus norethisterone acetate combined with letrozole for the treatment of ovarian endometriotic cysts: a patient preference study. Eur J Obstet Gynecol Reprod Biol. 2014; 174:117-22.

14. Seal SL, Kamilya G, Mukherji J, De A, Ghosh D, Majhi AK. Aromatase inhibitors in recurrent ovarian endometriomas: report of five cases with literature review. Fertil Steril. 2011;95(1):291-315.

15. Vignali M, Belloni GM, Pietropaolo G, Barbasetti Di Prun A, Barbera V, et al. Effect of dienogest therapy on the size of the endometrioma. Gynecol Endocrinol. 2020;36(8):723-7.

16. Taniguchi F, Enatsu A, Ota I, Toda T, Arata K, Harada T. Effects of low dose oral contraceptive pill containing drospirenone/ethinylestradiol in patients with endometrioma. Eur J Obstet Gynecol Reprod Biol. 2015;191:116-20.

17. Xholli A, Filip G, Previtera F, Cagnacci A. 2019s. Modification of endometrioma size during hormone therapy containing dienogest. Gynecol Endocrinol. 2019;36(6):545-9.

18. Osteen KG, Igarashi TM, Bruner-Tran KL. 2003. Progesterone action in the human endometrium: induction of a unique tissue environment which limits matrix metalloproteinase (MMP) expression. Front Biosci. 2003;8(1):78-86.

19. Mousa NA, Bedaiwy MA, Casper RF. Aromatase inhibitors in the treatment of severe endometriosis. Obstet Gynecol. 2007;109(6):1421-3.

20. Taniguchi F, Enatsu A, Ikebuchi A, Yamane E, Moriyama M, Murakami J, et al. Efficacy of norethisterone in patients with ovarian endometrioma. Yonago Acta Medica. 2017;60(3):182-5.

21. Ailawadi RK, Jobanputra S, Kataria M, Gurates B, Bulun SE. Treatment of endometriosis and chronic pelvic pain with letrozole and norethindrone acetate: a pilot study. Fertil Steril. 2004;81(2):290-6.

22. Remorgida V, Abbamonte HL, Ragni N, Fulcheri E, Ferrero S. Letrozole and norethisterone acetate in rectovaginal endometriosis. Fertil Steril. 2007;88(3):724-6.

23. Chwalisz K, Surrey E, Stanczyk FZ. The hormonal profile of norethindrone acetate: rationale for add- back therapy with gonadotropin-releasing hormone agonists in women with endometriosis. Reprod Sci. 2012;19(6):563-71.

24. Practice Committee of the American Society for Reproductive Medicine. Treatment of pelvic pain associated with endometriosis: a committee opinion. Fertil Steril. 2014;101(4):927-35.

25. Franke HR, van de Weijer PH, Pennings TM, van der Mooren MJ. Gonadotropin-releasing hormone agonist plus "add-back" hormone replacement therapy for treatment of endometriosis: a prospective, randomized, placebo-controlled, doubleblind trial. Fertil Steril. 2000;74(3):534-9.

26. Takayama K, Zeitoun K, Gunby RT, Sasano H, Carr BR, Bulun SE. 1998. Treatment of severe postmenopausal endometriosis with an aromatase inhibitor. Fertil Steril. 1998;69(4):709-13.

27. Razzi S, Fava A, Sartini A, De Simone S, Cobellis L. Petraglia F. 2004. Treatment of severe recurrent endometriosis with an aromatase inhibitor in a young ovariectomised woman. BJOG. 2004;111(2):182-4.

28. Fatemi HM, Al-Turki HA, Papanikolaou EG, Kosmas L, De Sutter P, Devroey P. Successful treatment of an aggressive recurrent post-menopausal endometriosis with an aromatase inhibitor. Reprod Biomed Online. 2005;11(4):455-7.

29. Hefler LA, Grimm C, van Trotsenburg M, Nagele F. Role of the vaginally administered aromatase inhibitor anastrozole in women with rectovaginal endometriosis: a pilot study. Fertil Steril. 2005;84(4):1033-6.

30. Amsterdam LL, Gentry W, Jobanputra S, Wolf M, Rubin SD, Bulun SE. 2005. Anastrazole and oral contraceptives: a novel treatment for endometriosis. Fertil Steril. 2005;84(2):300-4.

31. Remorgida V, Abbamonte HL, Ragni N, Fulcheri E, Ferrero S. Letrozole and desogestrel-only contraceptive pill for the treatment of stage IV endometriosis. ANZ J Obstet Gynaecol. 2007;47(3):222-5.

32. Madny EH. 2014. Efficacy of letrozole in treatment of endometriosis-related pain. Middle East Fertil Soc J. 2014;19:64-8.

33. Verma A, Konje JC. 2009. Successful treatment of refractory endometriosis-related chronic pelvic pain with aromatase inhibitors in premenopausal patients. Eur J Obstet Gynecol Reprod Biol. 2009;143(2):1125.

34. Muneyyirci-Delale O, Anopa J, Charles C, Mathur D, Parris R, Cutler JB, Salame G, Abulafia O. Medical management of recurrent endometrioma with long-term norethindrone acetate. Int $\mathrm{J}$ Wom Health. 2012;4:149.

35. Del Forno S, Mabrouk M, Arena A, Mattioli G, Giaquinto I, Paradisi R, Seracchioli R. 2019. Dienogest or Norethindrone acetate for the treatment of ovarian endometriomas: Can we avoidsurgery? Eur J Obstet Gynecol Reprod Biol. 2019;238:120-4.

36. Abushahin F, Goldman KN, Barbieri E, Milad M, Rademaker A, Bulun SE. 2011. Aromatase inhibition 
for refractory endometriosis-related chronic pelvic pain. Fertil Steril. 2011;96(4):939-42.

37. Badawy AM, Elnashar AM, Mosbah AA. 2012. Aromatase inhibitors or gonadotropin-releasing hormone agonists for the management of uterine adenomyosis: a randomized controlled trial. Nordic feder Soc Obstet Gynecol. 2012;91:489-95.

38. Polyzos NP, Fatemi HM, Zavos A, Grimbizis G, Kyrou D, Velasco JG, et al. Aromatase inhibitors in post-menopausal endometriosis. Reprod Biol Endocrinol. 2011;9(1):90.

39. Pavone ME, Bulun SE. 2012. Aromatase inhibitors for the treatment of endometriosis. Fertil Steril. 2012;98(6):1370-9.

40. Buzdar AU. 2004. The ATAC (Arimidex®, Tamoxifen, alone or in combination) trial: an update. Clin Breast Cancer. 2004;5:6-12.

41. Jakesz R, Jonat W, Gnant M, Mittlboeck M, Greil R, Tausch C, et al. Switching of postmenopausal women with endocrine-responsive early breast cancer to anastrozole after 2 years' adjuvant tamoxifen: combined results of ABCSG trial 8 and ARNO 95 trial. Lancet. 2005;366(9484):455-62.

42. Hillner BE, Ingle JN, Chlebowski RT, Gralow J, Yee GC, Janjan NA, et al. American Society of Clinical Oncology 2003 update on the role of bisphosphonates and bone health issues in women with breast cancer. J Clin Oncol. 2003;21(21):404257.

43. Shippen ER, West Jr WJ. 2004. Successful treatment of severe endometriosis in two premenopausal women with an aromatase inhibitor. Fertil Steril. 2004;81(5):1395-8.

Cite this article as: Ansary SA, Ishrat S, Banu J, Fatima P, Nasreen F, Jahan I, et al. Evaluation of the effect of aromatase inhibitor in reducing the size of endometrioma. Int J Reprod Contracept Obstet Gynecol 2021;10:1295-302. 